\title{
Ecological niche models and patterns of richness and endemism of the southern Andean genus Eurymetopum (Coleoptera, Cleridae)
}

\author{
Tania Escalante ${ }^{1}$, Miguel Linaje ${ }^{2}$, Patricia Illoldi-Rangel ${ }^{2,3}$, Miguel Rivas $^{4}$, Patricia Estrada ${ }^{4}$, \\ Francisca Neira ${ }^{4} \&$ Juan J. Morrone ${ }^{1}$
}

${ }^{1}$ Museo de Zoología "Alfonso L. Herrera”, Departamento de Biología Evolutiva, Facultad de Ciencias, Universidad Nacional Autónoma de México, Apdo. Postal 70-399, 04510 Mexico, D. F., Mexico.jjm@hp.fciencias.unam.mx

${ }^{2}$ Laboratorio de Sistemas de Información Geográfica, Instituto de Biología, Universidad Nacional Autónoma de México, Apdo. Postal 70-153, 04510 Mexico, D. F., Mexico.

${ }^{3}$ Biodiversity and Biocultural Conservation Laboratory, Section of Integrative Biology, University of Texas at Austin, Austin, TX 78712-1180, USA.

${ }^{4}$ Instituto de Entomología, Universidad Metropolitana de Ciencias de la Educación, José Pedro Alessandri 774, CP 7760197, Ñuñoa, Santiago, Chile.

\begin{abstract}
Ecological niche models and patterns of richness and endemism of the southern Andean genus Eurymetopum (Coleoptera, Cleridae). Eurymetopum is an Andean clerid genus with 22 species. We modeled the ecological niches of 19 species with Maxent and used them as potential distributional maps to identify patterns of richness and endemicity. All modeled species maps were overlapped in a single map in order to determine richness. We performed an optimality analysis with NDM/VNDM in a grid of $1^{\circ}$ latitude-longitude in order to identify endemism. We found a highly rich area, located between $32^{\circ}$ and $41^{\circ}$ south latitude, where the richest pixels have 16 species. One area of endemism was identified, located in the Maule and Valdivian Forest biogeographic provinces, which extends also to the Santiago province of the Central Chilean subregion, and contains four endemic species (E. parallelum, E. prasinum, E. proteus, and E. viride), as well as 16 non-endemic species. The sympatry of these phylogenetically unrelated species might indicate ancient vicariance processes, followed by episodes of dispersal. Based on our results, we suggest a close relationship between these provinces, with the Maule representing a complex area.
\end{abstract}

KEYWORDS. Andean region; Central Chilean subregion; Maxent; NDM; Subantarctic subregion.

RESUMEN. Modelos de nicho ecológico y patrones de riqueza y endemismo del género andino austral Eurymetopum (Coleoptera, Cleridae). Eurymetopum es un género de cléridos andinos con 22 especies. Modelamos los nichos ecológicos de 19 especies con Maxent y los utilizamos como mapas de distribución potencial para identificar patrones de riqueza y endemismo. Todos los mapas de las especies se superpusieron en un mapa único para determinar la riqueza. Realizamos un análisis de optimalidad con NDM/VNDM en una cuadrícula de $1^{\circ}$ de latitud-longitud para identificar el endemismo. Hallamos un área de mayor riqueza, localizada entre $\operatorname{los} 32^{\circ}$ y $41^{\circ}$ de latitud sur, donde los pixeles más ricos poseen 16 especies. Se identificó un área de endemismo en las provincias biogeográficas del Maule y el Bosque Valdiviano, la cual se extiende también a la provincia de Santiago de la subregión Chilena Central, y que contiene cuatro especies endémicas $(E$. parallelum, E. prasinum, E. proteus y E. viride), así como 16 especies no endémicas. La simpatría de estas especies filogenéticamente no relacionadas podría indicar antiguos procesos de vicarianza, seguidos de episodios de dispersión. Con base en nuestros resultados, sugerimos una relación cercana entre estas provincias, representando el Maule un área compleja.

PALABRAS CLAVE. Maxent; NDM; Región Andina; subregión Chilena Central; subregión Subantártica.

The high number of insect species represents a challenge for biodiversity studies. Additionally, their distributional data exhibit a higher level of uncertainty than other groups (like mammals, birds, plants, etc.), complicating the generation of databases to identify biodiversity patterns. Thus, studies about these patterns are usually undertaken for specific groups whose geographic distribution and ecological characteristics are better known, like ants in South America (Ruggiero 2001).

South America has been divided into the Neotropical and Andean regions and the South American Transition Zone (Morrone 2006). The Andean region, which extends basically in central Chile and Patagonia, is equivalent to southern South America (Marino et al. 2001). Most of the Andean biota originally evolved in Patagonia and then gradually spread northwards, into the South American Transition Zone, during Tertiary and Pleistocene (Kuschel 1969; Morrone 1994a). The Andean region comprises three subregions: Central Chilean, Subantarctic and Patagonian (Morrone 2006). The Central Chilean subregion extends in central Chile, between 30 and $34^{\circ}$ south latitude. The Subantarctic subregion comprises the austral Andes from $37^{\circ}$ to Cabo de Hornos, the archipelago of southern Chile and Argentina, and the Malvinas, South Georgia, and Juan Fernandez islands. It is divided into six provinces: Maule, Valdivian Forest, Magellanic Forest, Magellanic Moorland, Juan Fernández Islands, and Malvinas Islands. The Patagonian subregion extends in southern 
Argentina, from central Mendoza, widening through Neuquén, Río Negro, Chubut, and Santa Cruz, to northern Tierra del Fuego; and reaching Chile in Aisén and Magallanes. Some authors suggested that the Subantarctic and Central Chilean subregions are biotically related (Morrone 1994a; Morrone et al. 1997). In particular, a cladistic biogeographic analysis based on weevil species (Coleoptera: Curculionidae) suggested a close relationship between the Maule and Valdivian Forest biogeographic provinces with the Central Chilean subregion (Posadas \& Morrone 2001).

Eurymetopum Blanchard, 1844 (Coleoptera, Cleridae) is an Andean genus with 22 species, mainly associated to broadleaf evergreen forest from central and southern Chile, with preference for the Valdivian temperate forest, although some species are also distributed in the Subantarctic evergreen forest (Solervicens 1986, 2002, 2005). Species of Eurymetopum are distributed between $30^{\circ}$ and $55^{\circ} \mathrm{S}$ in Chile and Argentina, occupying a narrow strip in the eastern slope of the Andes (Solervicens 1986, 2002). The taxonomy and geographical distribution of the species of this genus have been studied extensively (Solervicens 1980, 1986, 1987, 1992, 1993, 2001, 2002, 2005; Solervicens \& Rodríguez 1985; Solervicens \& Huarapil 1992), so we believe that their biogeographic patterns may be investigated fruitfully.

Distributional patterns are discovered from individual distributional areas, which are inferred from data points of records in literature, collections and field work. Distributional areas obtained exclusively from data points, however, may be under-representing the real area of occupancy of a species. In order to improve the distributional maps of species obtained from data points, species' ecological niche modelling may be used (Stockwell \& Peters 1999). These models have been widely used in recent years (see Guisan \& Thuiller 2005), and their use as potential distributional areas may improve identification of biogeographical patterns (Escalante et al. 2007). Maximum entropy or Maxent (Phillips et al. 2006) is an efficient algorithm to develop ecological niche models (see Illoldi \& Escalante 2008; Peterson et al. 2007).

Richness and endemism are the main distributional patterns used to characterize biodiversity. Species richness is the most frequently used measurement of biodiversity (Gaston 1996; Moreno 2001). It is measured as the number of species present in a sample, in this case, a geographic area. On the other hand, endemism is referred to exclusivity to a geographic area, and it is used to discover patterns of biogeographical homology (Morrone 2001). Areas of endemism are areas of non-random distributional congruence among different taxa, and there are several methods to identify them (Morrone 1994b; Szumik et al. 2002; Szumik \& Goloboff 2004; Deo \& DeSalle 2006; Moline $\&$ Linder 2006). The optimality method (Szumik et al. 2002; Szumik \& Goloboff 2004) computes an index of endemicity based on the presence of a species in a particular combination of grid-cells in a grid, and is implemented in NDM/VNDM software (Goloboff 2005). This algorithm has proven to perform better than other methods under certain "noise" conditions (Casagranda \& Taher 2007).

We analyze herein the distributional patterns of richness and endemicity of 22 species of Eurymetopum in austral South America, based on ecological niche models projected as potential distributional areas of species.

\section{MATERIALAND METHODS}

Ecological niche modeling. - We compiled a database with 498 specimen records of 22 species of Eurymetopum from Chile and Argentina (Solervicens 1986; Neira \& Rivas 2007; see Appendix for the list of species and the number of records). Our first area of study comprises a grid with extreme coordinates $10^{\circ} 30^{\prime}-57^{\circ} 00^{\prime}$ south latitude and $48^{\circ} 30^{\prime}-79^{\circ} 00^{\prime}$ west longitude. It includes basically the South American Transition Zone (except the Northern Andean Paramo province, Morrone 2006) and the Andean region.

We modeled only 19 species with more than five records (E. breve, E. inerme and E. vittula were not modeled, although they are considered in the discussion) with Maxent 2.3 (Phillips et al. 2006). We used 19 bioclimatic variables (Hijmans et al. 2005; http://www.worldclim.org/; annual mean temperature, mean diurnal range, isothermality, temperature seasonality, maximum temperature of warmest month, minimum temperature of coldest month, temperature annual range, mean temperature of wettest quarter, mean temperature of driest quarter, mean temperature of warmest quarter, mean temperature of coldest quarter, annual precipitation, precipitation of wettest month, precipitation of driest month, precipitation seasonality, precipitation of wettest quarter, precipitation of driest quarter, precipitation of warmest quarter, and precipitation of coldest quarter), four topographic variables (http://edc.usgs.gov/ products/elevation/gtopo30/hydro/index.html; elevation, compound topographic index, aspect and slope), and 12 Modis satellite images (corresponding to average monthly surface reflectance values drawn from the normalized difference vegetation index (NDVI; for years 1992, 1993 and 1995). All the environmental variables were re-sampled to $0.02^{\circ}$ of resolution.

Ecological niche modeling for species with more than 15 records was performed using the default parameters (maximum iterations to 500 and using convergence threshold in 1.0E-5); and for species with less than 15 records, using the default parameters, varying maximum iterations to 350 and convergence threshold in 1.0E-5 (Pawar et al. 2007). The models of ecological niche were projected as maps of potential distributional areas, choosing all pixels beginning with the probability that coincides with all data point of presence of each species (Illoldi-Rangel et al. 2008).

Richness patterns. - The maps of potential distributional areas to each species were summed to obtain a unique map showing the number of predicted species in each pixel. We identified the pixels with the highest number of predicted species, namely the potential areas with highest species richness.

Endemism patterns. - We used the models obtained to undertake an analysis of endemicity using the optimality criteria in NDM/VNDM (Szumik et al. 2002; Szumik \& Goloboff, 
2004; Goloboff 2005). The study area was overlapped to a grid of 218 grid-cells of $1^{\circ}$ latitude-longitude. A matrix was built coding the presence of a species in a grid-cell with " 1 ", and the absence with " 0 " (see Appendix). This matrix was run in NDM/VNDM (Goloboff 2005), using the default parameters (save sets of areas with two or more endemic species, save sets with score above to 2.000 , and edge proportion option). As we constructed our matrix based on ecological niche models, it was not necessary to use "fill" and "assume" options of Szumik \& Goloboff (2004). We chose optimal sets that were above $50 \%$ different (in endemic species) to the highest score.

\section{RESULTS ANDDISCUSSION}

Ecological niche modeling. - We obtained 19 ecological niche models, one per species, projected as their potential distributional areas. Models were compared with the distributional maps and latitudinal distributions of Solervicens $(1987,2005)$, and were found to be consistent with them, except for a few overpredictions. We confirm the presence of Eurymetopum in central and southern Chile, with some species predicted also for Argentina. Although we still lack records, three species are predicted to be distributed in Argentina, but with low probabilities: E. eburneocinctum, E. modestum and E. rubidum. Moreover, E. eburneocinctum and E. modestum were predicted to be present in northern Chile, in the Atacama and Coastal Peruvian Desert biogeographic provinces, both with low probabilities. This coincides with Solervicens (2005), who noted that E. eburneocinctum, E. modestum and E. semirufum have wide distribution. Some species were predicted to the south: E. fulvipes to the Magellanic Moorland province, and E. modestum and E. rubidum even to the Magellanic Forest, Central Patagonian and Malvinas Islands provinces, all of them predicted with low probabilities. Furthermore, the predicted distribution of E. frigidum and E. longulum exceed the distributional latitudinal limit of $26^{\circ}$ suggested by Solervicens (2005).

Richness patterns. - Eurymetopum is basically distributed in the Andean region, with most of the species found between $32^{\circ}-41^{\circ}$ south latitude (Fig. 1). In these places, the non-modeled species are also distributed. This area is located in the Chilean matorral and Valdivian temperate forest ecoregions (http:// www.worldwildlife.org/science/ecoregions/item1847.html), in dry, sub-humid and humid ombrotypes (Luebert \& Pliscoff, 2006). The main vegetation types in this area are sclerophyll woodlands and forests and spiny forests (Luebert \& Pliscoff 2006). Other taxa showing a similar richness in the area are Asteraceae (at $33^{\circ}-34^{\circ}$, Moreira-Muñoz \& Muñoz-Schick 2007), Senecio (Rovito et al. 2004) and weevils of the tribe Aterpini (Morrone 1996).

The area with the highest predicted richness of species of Eurymetopum is located in a grid-cell of the Santiago biogeographic province, between $36^{\circ}-37^{\circ}$ latitude and $71^{\circ}-72^{\circ}$ longitude (Fig. 1). A second rich area is located between $35^{\circ}$ $39^{\circ}$ latitude and consists of eight grid-cells containing 180 pixels with 15 predicted species. None of these grid-cells

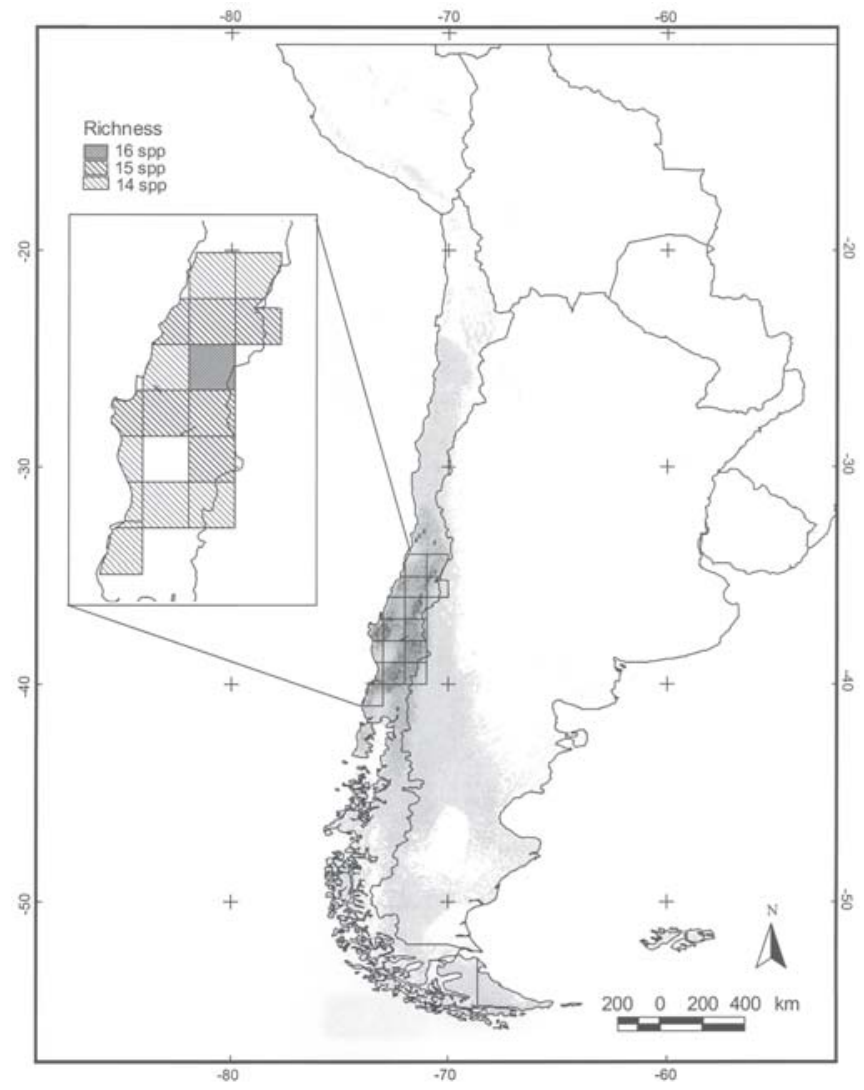

Fig. 1. Map of predicted species richness for 19 species of Eurymetopum modeled with Maxent. Data points for E. breve, E. inerme and E. vittula (not modeled) and richest grid-cells are shown.

contains non-modeled species. Other rich grid-cells are located in the southern Santiago province; in the intersection between the Santiago and Central Patagonian provinces; in the intersection between the Santiago, Central Patagonian and Prepunan provinces; in the northern part of the Maule province; in the intersection of the Santiago and Maule provinces; in the intersection of the Santiago, Maule and Central Patagonian provinces; and in the intersection of the Maule and Central Patagonian provinces.

Endemism patterns. - We found a single area of endemism comprised of 42 grid-cells, located between $35^{\circ}-47^{\circ}$ latitude (Fig. 2), with a score of 3.512. It has four endemic species: $E$. parallelum (endemicity score of 0.8586$)$, E. prasinum (0.8913), E. proteus $(0.8928)$, and E. viride (0.8695). All the remaining species, excepting $E$. breve and E. inerme (both not modeled) are also distributed in the area. This area of endemism is situated in the Maule and Valdivian Forest biogeographic provinces, both belonging to the Subantarctic subregion, and its northern part lies in the Santiago province, which belongs to the Central Chilean subregion. A small part of this area of endemism extends to the northwestern portion of the Central Patagonian biogeographic province; however, no data points have been recorded for this province, so it may represent an overprediction of the Maxent models. 


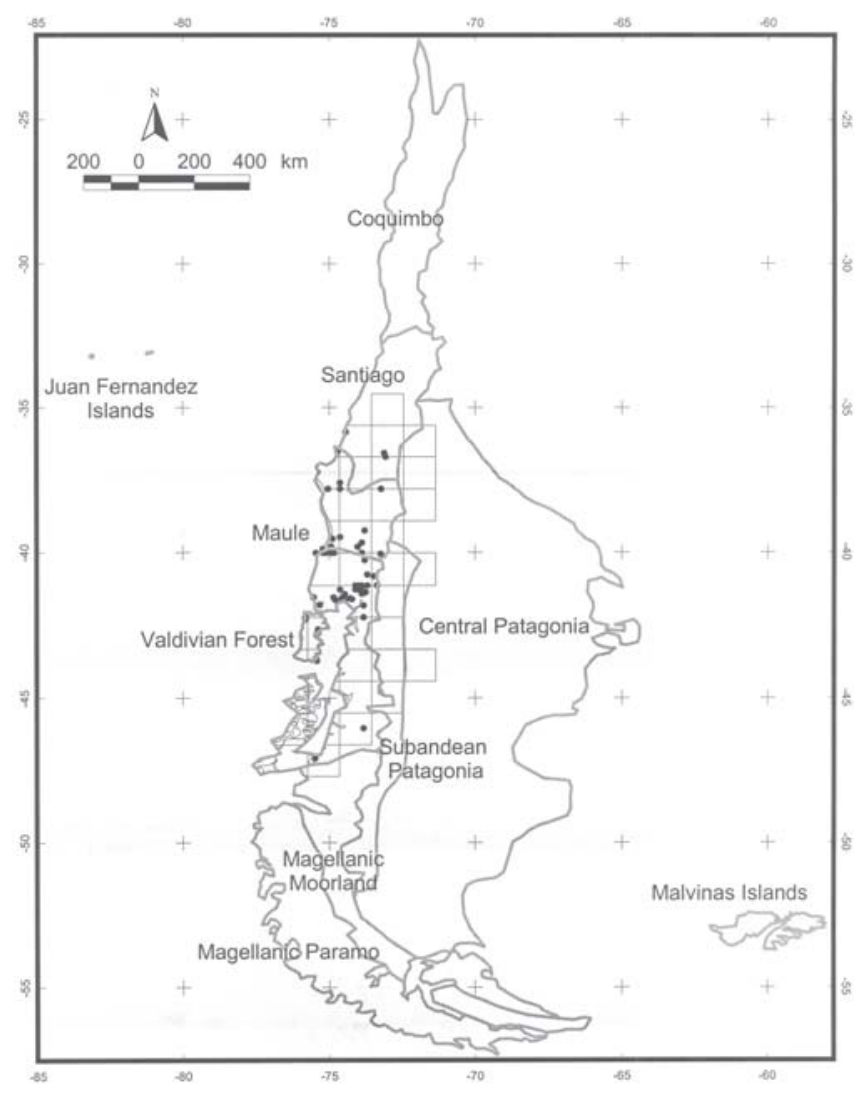

Fig. 2. Area of endemism found for the species of Eurymetopum, based on ecological niche models and a grid of $1^{\circ}$ latitude-longitude. Data points of four endemic species and provinces of the Andean region (sensu Morrone 2006) are shown.

The altitudes of the area of endemism vary between 500$4000 \mathrm{~m}$, but altitudes between $500-2000 \mathrm{~m}$ are predominant. Sclerophyll woodlands and forests, evergreen forest and laurelleaved forests are the dominant vegetation types (Luebert \& Pliscoff 2006). The richest area of species coincides with the northern grid-cells of the area of endemism, in the southern portion of the Santiago province (Central Chilean subregion). Peña (1966) recognized 18 entomological regions in Chile, where the Northern Valdivian Forest and Valdivian Forest regions correspond to our area of endemism.

Neira \& Rivas (2007) identified three areas of endemism using the data points of all the 22 species of Eurymetopum in grid-cells of $1^{\circ}$, located in Quillota-Teno (between $32.9^{\circ}-34.9^{\circ}$ latitude), Los Vilos-Río Negro ( $31.9^{\circ}-41.9^{\circ}$ latitude) and LongavíRío Negro (35.9 $-41.9^{\circ}$ latitude), identifying each with three or four endemic species. Of the endemic species, only E. prasinum and $E$. viride were identified as endemic in our analysis. The area of endemism identified herein is equivalent to their third area de endemism, but our area is bigger, extending to $47^{\circ}$. We did not find their former area of endemism, maybe because our models expand the distributional areas; and their latter area is partially nested within the third one. Our area of endemism, however, has the highest score (3.512) with respect to Neira \& Rivas's (2007) areas of endemism (3.027, 2.398, and 2.824).
Potential distributional models can improve the ruggedness in the identification of areas of endemism.

Solervicens (1987) used a cladistic biogeographic approach to analyze the relationships between the areas of endemism of Eurymetopum. He arranged most of the species into three groups of areas. Our endemic species belong to the three groups (E. parallelum is not assigned to any group, E. viride belongs to the E. modestum group, E. proteus to the $E$. eburneocinctum group, and E. prasinum to the E. maculatum group), and all of them are distributed in the Valdivian forest. The sympatry of these phylogenetically unrelated species might indicate ancient vicariance processes, followed by episodes of dispersal, as suggested by Solervicens (1987), who also postulated that the Valdivian forest was the original habitat of Eurymetopum, and that its species extended subsequently to xeric and mesic habitats. Solervicens (2005) mentioned that Eurymetopum has a Gondwanic origin, and its ancestral populations were isolated because the development of arid habitats segregated the temperate forest of Argentina and Chile.

Morrone (1996) undertook a panbiogeographic analysis of 23 species of Aterpini (Coleoptera: Curculionidae) in Central Chile, and the Maule, Valdivian Forest and Magellanic Forest provinces. He found two generalized tracks (Central ChileMaule and Maule-Valdivian Forest-Magellanic Forest) and identified the Maule, where both generalized tracks overlapped, as a node. Rovito et al. (2004) suggested a floristic division at $35^{\circ}$ approximately. Moreira-Muñoz \& Muñoz-Schick (2007) also suggested the existence of a panbiogeographic node in this zone. We conclude also that the Maule is a complex biotic area for Eurymetopum, because the northern portion of the Maule province and the southern portion of the Central Chilean subregion contain the richest grid-cells, and the area of endemism begins in this boundary.

Posadas \& Morrone (2001) hypothesized that the Central Chilean subregion is the sister group of the two septentrional provinces of the Subantarctic subregion: the Maule and Valdivian Forest. Posadas et al. (1997) also suggested that the northern Subantarctic subregion and southern Central Chilean subregion have complex relationships. Estrada et al. (2007) identified an area of endemism, based on insect and plant data, between $27^{\circ}-38^{\circ}$ latitude, which includes part of the Central Chilean subregion and the Maule province. These results suggest a complex area in this latitude; however, further studies are necessary to contrast this hypothesis.

Acknowledgments. Jaime Solervicens commented on a preliminary version of the manuscript and made important suggestions. Two anonymous reviewers made useful suggestions. Gerardo Rodríguez helped us with the GIS and the spatial analysis. This work was partially done during a postdoctoral stay of T. Escalante at the Laboratorio de Análisis Espaciales of the Instituto de Biología, Universidad Nacional Autónoma de Mexico (PROFIP, DGAPA).

\section{REFERENCES}

Casagranda, D. \& L. Taher. 2007. Elementos bióticos, endemismo y parsimonia: Estudio de casos de distribuciones hipotéticas. 
Darwiniana 45 (supl.): 37-38.

Deo, A. J. \& R. DeSalle. 2006. Nested areas of endemism analysis. Journal of Biogeography 33: 1511-1526.

Escalante, T.; V. Sánchez-Cordero; J. J. Morrone \& M. Linaje. 2007. Areas of endemism of Mexican terrestrial mammals: A case study using species' ecological niche modeling, Parsimony Analysis of Endemicity and Goloboff fit. Interciencia 32: 151-159.

Estrada, P.; F. Neira \& M. Rivas. 2007. Análisis biogeográfico de Chile Central: Aplicación del programa ndm/vndm para la búsqueda de áreas de endemismo. Entomología Mexicana 6: 1261-1266.

Gaston, K. J. 1996. Species richness: Measure and measurement, p. 77113. In: K. J. Gaston (ed.). Biodiversity, a biology of numbers and difference. Cambridge, Blackwell Science, 396 p.

Goloboff, P. 2005. NDM/VNDM v. 2.5. Programs for identification of areas of endemism. http://www.zmuck.dk/public/philogeny/ endemism.

Guisan, A. \& W. Thuiller. 2005. Predicting species distribution: Offering more than simple habitat models. Ecology Letters 8: 993-1009.

Hijmans, R. J.; S. Cameron \& J. Parra. 2005. WorldClim v. 1.3. University of California, Berkeley (http://www.worldclim.org).

Illoldi, P. \& T. Escalante. 2008. De los modelos de nicho ecológico a las áreas de distribución geográfica. Biogeografía 3: 7-12.

Illoldi-Rangel, P.; T. Fuller; M. Linaje; C. Pappas; V. Sanchez-Cordero \& S. Sarkar. 2008. Solving the maximum representation problem to prioritize areas for the conservation of terrestrial mammals at risk in Oaxaca. Diversity and distributions 14: 493-508.

Kuschel, G. 1969. Biogeography and ecology of South American Coleoptera. In: Fittkau, E. J. J. Illies, H. Klinge, G. H. Schwabe \& H. Sioli (eds.), Biogeography and ecology in South America, The Hague, Junk, vol. 2, 709-722 p.

Luebert, F. \& P. Pliscoff. 2006. Sinopsis bioclimática y vegetacional de Chile. Santiago, Editorial Universitaria. 316 p.

Marino, P. I.; G. R. Spinelli \& P. Posadas. 2001. Distributional patterns of species of Ceratopogonidae (Diptera) in southern South America. Biogeographica 77: 113-122.

Moline, P. M. \& H. P. Linder. 2006. Input data, analytical methods and biogeography of Elegia (Restionaceae). Journal of Biogeography 33: $47-62$.

Moreira-Muñoz, A. \& M. Muñoz-Schick. 2007. Classification, diversity, and distribution of Chilean Asteraceae: Implications for biogeography and conservation. Diversity and Distributions 13: $818-828$.

Moreno, C. E. 2001. Métodos para medir la biodiversidad. Zaragoza, Manuales y Tesis SEA, vol. 1, 84 p.

Morrone, J. J. 1994a. Distributional patterns of species of Rhytirrhinini (Coleoptera: Curculionidae) and the historical relationships of the Andean provinces. Global Ecology and Biogeography Letters 4: $188-194$.

Morrone, J. J. 1994b. On the identification of areas of endemism. Systematic Biology 43: 438-441.

Morrone, J. J. 1996. Distributional patterns of the South American Aterpini (Coleoptera: Curculionidae). Revista de la Sociedad Entomológica Argentina 55: 131-141.

Morrone, J. J. 2001. Homology, biogeography and areas of endemism. Diversity and Distributions 7: 297-300.

Morrone, J. J. 2006. Biogeographic areas and transition zones of Latin America and the Caribbean Islands based on panbiogeographic and cladistic analyses of the entomofauna. Annual Review of Entomology 51: 467-494.

Morrone, J. J.; L. Katinas \& J. V. Crisci. 1997. A cladistic biogeographic analysis of Central Chile. Journal of Comparative Biology 2: $25-41$.

Neira, M. F. \& M. A. Rivas. 2007. Búsqueda de áreas de endemismo para el género Eurymetopum Blanchard 1844 (Coleoptera: Cleridae), mediante el software NDM/VNDM (Goloboff, 2005). Thesis. Santiago, Universidad Metropolitana de Ciencias de la Educación. 66 pp.

Pawar, S.; M. S. Koo; C. Kelley; M. F. Ahmed; S. Chaudhuri \& S. Sarkar. 2007. Conservation assessment and prioritization of areas in northeast India: Priorities for amphibians and reptiles. Biological
Conservation 136: 346-361.

Peña, L. E. 1966. A preliminary attempt to divide Chile into entomofaunal regions, based on the Tenebrionidae (Coleoptera). Postilla 97: 1-17.

Peterson, T. A; M. Papes \& M. Eaton. 2007. Transferability and model evaluation in ecological niche modeling: A comparison of GARP and Maxent. Ecography 30: 550-560.

Phillips, S. J.; R. P. Anderson \& R. E. Schapire. 2006. A maximum entropy modelling of species geographic distributions. Ecological Modelling 190: 231-259.

Posadas, P.; J. M. Estévez \& J. J. Morrone. 1997. Distributional patterns and endemism areas of vascular plants in the Andean subregion. Fontqueria 48: $1-10$.

Posadas, P. \& J. J. Morrone. 2001. Biogeografía cladística de la subregión Subantártica: Un análisis basado en taxones de la familia Curculionidae (Insecta: Coleoptera), p. 267-271. In: J. Llorente \& J. J. Morrone (eds.). Introducción a la biogeografía en Latinoamérica: Teorías, conceptos, métodos y aplicaciones. Mexico, D. F., Las Prensas de Ciencias, 277 p.

Rovito, S. M.; M. T. K. Arroyo \& P. Pliscoff. 2004. Distributional modelling and parsimony analysis of endemicity of Senecio in the Mediterranean-type climate area of Central Chile. Journal of Biogeography 31: 1623-1636.

Ruggiero, A. 2001. Interacciones entre la biogeografía ecológica y la macroecología: Aportes para comprender los patrones espaciales en la diversidad biológica, p. 81- 94. In: J. Llorente \& J. J. Morrone (eds.). Introducción a la biogeografía en Latinoamérica: Teorías, conceptos, métodos y aplicaciones. Mexico, Las Prensas de Ciencias, $277 \mathrm{p}$.

Solervicens, J. 1980. Dos nuevas especies del género Eurymetopum Blanchard 1842-1843 de la región central de Chile y consideraciones biogeográficas y evolutivas para una de ellas (Coleoptera: Cleridae). Anales del Museo de Historia Natural de Valparaíso 13: 193-207.

Solervicens, J. 1986. Revisión taxonómica del género Eurymetopum Blanchard, 1844 (Coleoptera, Cleridae, Phyllobaeninae). Acta Entomológica Chilena 13: 11-120.

Solervicens, J. 1987. Filogenia y biogeografía del género Eurymetopum Blanchard 1844 (Coleoptera: Cleridae: Phillobaeninae). Acta Entomológica Chilena 14: 127-154.

Solervicens, J. 1992. Variación geográfica de Eurymetopum eburneocinctum (Spinola, 1849) (Coleopera: Cleridae), descripción de subespecies y consideraciones biogeográficas. Acta Entomológica Chilena 17: 81-93.

Solervicens, J. 1993. Variación cromática en especies de Eurymetopum del grupo modestum (Coleoptera: Cleridae: Phyllobaeninae). Acta Entomológica Chilena 18: 101-103.

Solervicens, J. 2001. Clave para los géneros de Cleridae de Chile (Coleoptera). Acta Entomológica Chilena 25: 41-46.

Solervicens, J. 2002. Catálogo de los cléridos de Chile (Coleoptera: Cleridae). Acta Entomológica Chilena 26: 81-94.

Solervicens, J. 2005. Diversidad y endemismo de Cleridae (Coleoptera) del Parque Nacional Nahuelbuta, p. 324-339. In: C. Smith-Ramírez, J. J. Armesto \& C. Valdovinos (eds.), Historia, biodiversidad y ecología de los bosques costeros de Chile. Santiago de Chile, Editorial Universitaria, $710 \mathrm{p}$.

Solervicens, J. \& S. Huarapil. 1992. Ciclo de vida y formas juveniles de Eurymetopum multinotatum Pic, 1950 (Coleoptera: Cleridae: Phyllobaeninae). Acta Entomológica Chilena 19: 147-155.

Solervicens, J. \& L. Rodríguez. 1985. Sinonimias en especies de grupo maculatum del género Eurymetopum (Coleoptera: Cleridae). Acta Entomológica Chilena 19: 109-112.

Stockwell, D. \& D. Peters. 1999. The GARP modelling system: Problems and solutions to automated spatial prediction. International Journal of Geographic Information Systems 13: 143-158.

Szumik, C. A.; F. Cuezzo; P. A. Goloboff \& A. E. Chalup. 2002. An optimality criterion to determine areas of endemism. Systematic Biology 51: 806-816.

Szumik, A. C. \& P. Goloboff. 2004. Areas of endemism: An improved optimality criterion. Systematic Biology 53: 968-977. 
Appendix. Data matrix used in the NDM analysis. Columns (number of records between parenthesis): 1, Eurymetopum bispinossum (6); 2, E. brevevittatum (13); 3, E. eburneocinctum (42); 4, E. frigidum (28); 5 , E. fulvipes (20); 6, E. iridescens (18); 7, E. longulum (26); 8, E. maculatum (97); 9, E. maculipes (10); 10, E. modestum (58); 11, E. obscurum (12); 12, E. parallelum (15); 13, E. penai (5); 14, E. prasinum (18); 15, E. proteus (19); 16, E. rubidum (49); 17, E. semiprasinum (17); 18, E. semirufum (19); 19, E. viride (17); 20, E. breve (3); 21, E. inerme (2); 22, E. vittula (4).

\begin{tabular}{|c|c|}
\hline A $1-5$ & 0010000001000000000000 \\
\hline A2 $2-5$ & 0011001101001001000000 \\
\hline A $3-5$ & 0011001111001001000000 \\
\hline A3-6 & 1011001101000001100000 \\
\hline A4-5 & 0011001101001001000000 \\
\hline A4-6 & 1011001101001001100000 \\
\hline A5-4 & 0011001101000001000000 \\
\hline A5-5 & 0011001101001001100000 \\
\hline A5-6 & 0011001101001001100000 \\
\hline A6-4 & 0011001101001001000000 \\
\hline A6-5 & 1011001101001001100000 \\
\hline A6-6 & 1011001101000001100000 \\
\hline A7-4 & 0011001101001001000000 \\
\hline A7-5 & 1011001101001001100000 \\
\hline A7-6 & 0010001101000001000000 \\
\hline A $8-4$ & 0011001101001001100000 \\
\hline A $8-5$ & 101100110100100110000 \\
\hline A $8-6$ & 0010001100000001000000 \\
\hline A9-4 & 0011001111001001110000 \\
\hline A9-5 & 101100111100100111000 \\
\hline A $10-4$ & 1111101111001001110010 \\
\hline A $10-5$ & 101110111100100111000 \\
\hline A11-4 & 1111101111101001110100 \\
\hline A $11-5$ & 1111111111101001110100 \\
\hline A $11-6$ & 001111111100000111000 \\
\hline A $12-3$ & 1111111111100101110000 \\
\hline A $12-4$ & 1111111111101001111000 \\
\hline A $12-5$ & 1111111111101001110010 \\
\hline A $12-6$ & 0011111111000001110000 \\
\hline A $13-3$ & 1111111111100101111000 \\
\hline A $13-4$ & 1111111111110101111000 \\
\hline A $13-5$ & 1111111111110001110000 \\
\hline A $13-6$ & 0010011111000001000000 \\
\hline A $14-2$ & 0011111101110111111001 \\
\hline A $14-3$ & 0111111101110111111000 \\
\hline A $14-4$ & 1111111111110101111000 \\
\hline A $14-5$ & 0111111111000001110000 \\
\hline A $14-6$ & 0000000001001001000000 \\
\hline A $14-7$ & 0000000000000000000000 \\
\hline A $15-2$ & 1111111101110111111000 \\
\hline A $15-3$ & 1111111101110111111000 \\
\hline A $15-4$ & 1111111111110111111000 \\
\hline A $15-5$ & 0111111111010001111000 \\
\hline A $15-6$ & 0010000001001001000000 \\
\hline A $15-7$ & 0000000001000000000000 \\
\hline A $15-8$ & 0000000001000000000000 \\
\hline A $16-2$ & 0111110101110111111000 \\
\hline A $16-3$ & 0111110101110111111000 \\
\hline A $16-4$ & 0111111111110111111000 \\
\hline A $16-5$ & 0111111101010001111000 \\
\hline A $16-6$ & 0000000001000001000000 \\
\hline A $16-7$ & 0010000001000000000000 \\
\hline A $16-8$ & 0000000001000000000000 \\
\hline A $16-9$ & 0000000001000000000000 \\
\hline A $16-10$ & 0000000001000000000000 \\
\hline A $17-2$ & 0111110001110111111001 \\
\hline A $17-3$ & 0111110101110111111000 \\
\hline A $17-4$ & 0111111111110111111000 \\
\hline A $17-5$ & 0011001101000001110000 \\
\hline A $17-6$ & 0010000101000001000 \\
\hline
\end{tabular}

A $17-7$

A $17-8$

A17-9

A $17-10$

A $17-11$

A $18-2$

A 18-3

A 18-4

A 18-5

A 18-6

A 18-7

A 18-8

A 18-9

A $18-10$

A18-11

A 19-1

A 19-2

A19-3

A 19-4

A 19-5

A 19-6

A 19-7

A 19-8

A 19-9

A 19-10

A20-1

A 20-2

A20-3

A20-4

A 20-5

A20-6

A20-7

A20-8

A20-9

A20-10

A 20-11

A20-12

A21-1

A21-2

A21-3

A21-4

A21-5

A21-6

A21-7

A21-8

A21-9

A 21-10

A 21-11

A22-1

A22-2

A22-3

A22-4

A22-5

A22-6

A22-7

A22-8

A22-9

A 22-10

A23-0

A23-1

A23-2

A23-3

A23-4

A23-5

A23-6

A23-7

A23-8

A23-9

A23-10

A24-0
0010000001000001000000 0000000001000000000000 0000000001000000000000 0000000001000000000000 0000000001000000000000 0111110101110111111000 0111110001110111111000 0111111001110111111000 0011000101000001110000 0010000101001001100000 0010000001000001000000 0000000001000000000000 0000000001000000000000 0000000001000000000000 0000000001000000000000 0011110001010111001000 0011110001110111111000 0011111001110111111001 0011111011110111111000 0011000001000001110000 0010000101000001100000 0000000001000001000000 0000000001000001000000 0000000001000000000000 0000000001000001000000 0011110001010111111000 0011110001010111111000 0011110011110111111000 0011111011110111111000 0010000101001001110000 0010000101000001000000 0000000001000001000000 0000000001000001000000 0000000001000001000000 0010000001000001000000 0010000001000001000000 0010000001000000000000 0010110001010111101000 0011110001010111101000 0011110001110111111000 0011110001010111111000 0010000001001001000000 0010000001000001000000 0010000001000001000000 0000000001000001000000 0010000001000001000000 0010000001000001000000 0010000001000001000000 0010110001010111101000 0010110001010111111000 0011110001010111111000 0011110001010111111000 0000000001000001000000 0010000001000001000000 0010000001000001000000 0010000001000001000000 0010000001000001000000 0010000001000001000000 0000100001000101000000 0000110001010111001000 0010110001010111011000 0010110001010111111000 0010110001000001100000 0010000001000001000000 0010000001000001000000 0010000001000001000000 0010000001000001000000 0010000001000001000000 0010000001000001000000 0010100001000101000000 
A24-1

A24-2

A24-3

A24-4

A24-5

A24-6

A24-7

A24-8

A24-9

A25-0

A25-1

A25-2

A 25-3

A25-4

A25-5

A25-6

A25-7

A 25-8

A25-9

A 25-10

A26-0

A26-1

A26-2

A26-3

A26-4

A26-5

A26-6

A26-7

A 26-8

A 26-9

A 26-10

A27-0

A 27-1

A27-2

A27-3

A 27-4

A27-5

A27-6

A27-7

A27-8

A28-0

A28-1

A28-2

A28-3
0000100001000101000000

0010110001000101000000

0010110001000001100000

0010010001000001100000

0000000001000001000000

0000000001000001000000

0010000001000001000000

0010000001000001000000

0000000001000001000000

0000110001000001000000

0010100001000001000000

0010110001000001000000

0010000011000001000000

0010000001001001000000

0000000001000001000000

0000000001000001000000

0010000001000001000000

0010000001000001000000

0010000001000001000000

0010000001000001000000

0000100000000001000000

0000100001000001000000

0000110001000001000000

0010010001000001000000

0000000001000001000000

0000000001000001000000

0010000001000001000000

0010000001000001000000

0010000001000001000000

0010000001000001000000

0010000001000001000000

0000100000000001000000

0000110001000001000000

0000100001000001000000

0010000001000001000000

0010000001001001000000

0010000001000001000000

0010000001000001000000

0010000001000001000000

0010000001000001000000

0000100000000001000000

0000110001000001000000

0000100001000001000000

0010000001000001000000
A28-4

A28-5

A28-6

A28-7

A28-8

A29-0

A29-1

A 29-2

A 29-3

A29-4

A29-5

A29-6

A29-7

A30-0

A30-1

A $30-2$

A30-3

A30-4

A $30-5$

A30-6

A30-7

A31-1

A $31-2$

A $31-3$

A $31-4$

A31-5

A31-6

A31-7

A31-8

A32-2

A $32-3$

A $32-4$

A $32-5$

A32-6

A32-7

A $32-8$

A32-9

A $32-10$

A33-4

A33-5

A33-6

A33-7

A33-8

A33-9
0010000001001001000000 0010000001000001000000 0010000001000001000000 0010000001000001000000 0010000001000001000000 0000100001000001000000 0000100001000001000000 0000000001000001000000 0000000001000001000000 0000000001001001000000 0000000001000001000000 0000000001000001000000 0000000001000001000000 0000100000000001000000 0000100001000001000000 0000110001000001000000 0000000001000001000000 0000000001000001000000 0010000001000001000000 0000000001000001000000 0000000001000001000000 0000100000000001000000 0000110001000001000000 0000010001000001000000 0000000001000001000000 0010000001000001000000 0000000001000001000000 0000000001000001000000 0000000001000001000000 0000100000000001000000 0000100001000001000000 0000000001000001000000 0010000001000001000000 0010000001000001000000 0000000001000001000000 0000000001000001000000 0000000001000001000000 0000000001000001000000 0000000000000000000000 0000000001000001000000 0000000001000001000000 0000000001000001000000 0000000001000001000000 0000000001000001000000 